\title{
Development Of Interactive Multimedia Based On Balinesse Culture Contextual In Graphic Design Learning At Class X Multimedia In Smk Negeri 1 Sawan
}

\author{
I Gede Jaka Mahendra ${ }^{1 *}$, Kadek Agus Hendra Pujawan ${ }^{2}$
}

1,2 Politeknik Ganesha Guru, Denpasar, Bali

A R T I C L E I N F O Article history:

Received 20 May 2018

Received in revised

form

6 June 2018

Accepted 15 July 2018

Available online 25

August 2018

Keywords:

Interactive Multimedia, Dick and Carey, Graphic Design

\section{A B S T R A C}

The objectives to be achieved in this study were (1) to describe the design of interactive multimedia development based on Balinese culture on graphic design learning at class $X$ Multimedia in SMK Negeri 1 Sawan. (2) to describe the responses of content experts, design experts and media experts to the development of interactive multimedia based on Balinese Culture contextual on graphic design learning at Class $X$ Multimedia in SMK Negeri 1 Sawan. (3) to describe the response of the user / teacher teaching graphic design subjects to the development of interactive multimedia based on Balinese contextual culture on graphic design learning at Class X Multimedia in SMK Negeri 1 Sawan. (4) to describe the response of students in the form of individual trials, small group trials and field trials on the development of interactive multimedia based on Balinese Culture contextual on graphic design learning in Class $X$ Multimedia in SMK Negeri 1 Sawan. The interactive multimedia development model based on Balinese cultural contextual learning graphic design used Dick \& Carey model. In the process of designing multimedia products, content experts are required to adjust the material presented in interactive multimedia with the material provided at school, in this case the teacher is appointed as content expert, so the teacher's contribution in this study is to provide a syllabus of graphic design material. In addition to content experts, media experts and design experts are also needed to test the validity of interactive multimedia developed. After being valid, it will be implemented in school by giving a questionnaire to students whether the interactive multimedia developed in this study is suitable for use or not. The following are tests on aspects of display, graphics, program operation and grammar performed by media experts obtaining $85 \%$ of the calculation results in good qualifications. Tests on aspects of learning, curriculum and interface design conducted by learning design experts obtain a calculation of $89 \%$ in good qualifications. User/teacher responded well. Individual trials carried out received good responses. Small group trials obtained calculation results of $90 \%$ are in very good qualifications. Field trials that were carried out obtained a calculation of $87 \%$ in good qualifications. 


\section{Introduction}

In this globalization era, the understanding and application of information technology is much needed. The role of Information Technology has penetrated into all fields, one of them is education field. The role of Information Technology in the field of education is to help providing the educational information/messages to the educational components. The use of Information Technology has attractiveness both from the teaching staff and students with the hope of providing an effective and efficient contribution to the more optimal achievement of the educational goals.

One of the schools that has tried to develop multimedia in the learning process is SMK Negeri 1 Sawan, Buleleng. But in reality at that school it cannot fully implemented. This is due to the lack of human resources in the field of manufacturing and managing interactive multimedia. In addition, the available media is linear without a controller, so that the display is presented sequentially which is not in accordance with the character of students in class X Multimedia SMK Negeri 1 Sawan.

Based on interviews with the teachers of the basic graphic design subjects, the basic subjects of graphic design take a long time to understand and practice them, while the time allocation in school is very lacking. So a tool is needed in the learning process. In addition, the number of computers as practicum tools in schools made some students unable to participate in the lesson optimally, even though they had studied in groups. On the other hand, based on the results of interviews and analysis of the characteristics of students at SMK Negeri 1 Sawan, the students mostly come from rural areas so that expectations in developing interactive multimedia by using Balinese cultural contextual approaches can be greater. In addition students prefer to learn by watching animated shows, so that interactive multimedia in the display of his theory uses animation in the hope of increasing student responses in the process of learning graphic design.

Seeing these problems and conditions, it is necessary to develop an audio visual / multimedia based learning. This can provide great potential in changing the way a person learns, both getting information to adjusting information. Multimedia also provides opportunities for educators to develop learning techniques, methods and strategies. With multimedia it is expected that students will find it easier to determine what and how to understand information quickly and efficiently.

Research conducted by Mochamad Miswar Hadibin, Bambang Eka Purnama and Gesang Kritianto (2012) states that learning using interactive multimedia-based learning media increases students' interest and response in receiving subject matter. This has similarities with the development results that the author did.

This is in line with the results of Ling Wang's (2008) research in developing multimedia-based learning program software. The results show that programs developeded are effective in terms of student learning outcomes and provide recommendations to educators to consider adopting the program in their learning. Lee and Tseng (2008) in their research stated that, the use of digital content instruments in learning resulted in significant differences in student achievement when compared to traditional learning.

\section{Method}

The type of research chosen is Research and Development (R \& D). Research and Development (R \& D) is a research method used to produce certain products, and test the effectiveness of these products (Sugiyono, 2013: 407). This is in line with the opinion (Ghufron, 2007), Development research is a research model that aims to develop and validate education and learning products to improve and develop the quality of education and learning effectively and adaptably. Further development is defined as a process of translating design specifications into the physical form of Seels \& Richey (in Sudarma \& Tegeh, 2007). In this case it is clear that the main purpose of the development research is how to design and produce a media specification that will be developed.

There are 5 components of learning strategies, namely: (1) preliminary learning activities, (2) delivery of material, (3) participation of students, (4) tests, (5) follow-up activities. In order to improve students' understanding of subject matter and mastering the concepts, so that satisfying learning outcomes are needed an ICT-based learning strategy that is able to activate students in the teaching and learning process according to Dick \& Carey (in Uno 2007). In this case by using interactive multimedia based on Balinese cultural contextual.

The approach used in interactive multimedia development research is a contextual approach, Trianto (2008: 20) says that: "contextual learning is a learning concept that helps teachers associate between material taught with the real-world situation of students and encourage students to make connections between their knowledge and its application in their daily lives. In this case, learning is adapted to the characteristics of students in the X Multimedia class of SMK 1 Sawan, which is fonder of 
learning by viewing animated shows with Balinese cultural nuances. In this case the interactive multimedia developed is packaged with a controller button that provides theoretical explanations with an animated display and when practicing using video guides in designing. The following are the stages according to Dick and Carey.

Stage 1: In the early stages of developing interactive multimedia based on Balinese contextual culture, the author considers the success of making interactive multimedia and the character of the content presented, judging from the type of media that displays interactive buttons, sound, animation and learning guides in the form of video study guides, students will be interested in learning graphic design material delivered to this interactive multimedia.

Stage 2: Subjects developed in interactive multimedia based on contextual Balinese culture are the basic subjects of graphic design. Graphic Design is a subject given in class X Multimedia expertise program that presents the basics of design to practice design techniques using Corel draw software.

Stage 3: The steps taken in this stage are the process of collecting data related to basic competencies in graphic design subjects, in this case the researcher collects data provided by basic graphic design subject teachers.

Stage 4: In Corel Draw learning the researcher uses sources in the form of books and other teaching materials used in schools, in addition to the content guide adapting the 2013 curriculum at SMK Negeri 1 Sawan. So that the material presented in interactive multimedia is in accordance with the graphic design curriculum at SMK Negeri 1 Sawan.

Stage 4: Characteristics of students in SMK 1 Sawan that is more like learning to use multimedia-based teaching materials, which guides independence in solving a problem in learning graphic design, because of the lack of time allocation in school, students can study at home through the video guide presented in interactive multimedia.

Stage 5: Characteristics of students in SMK 1 Sawan, which are more like learning to use teaching materials based on multimedia, which guides independence in solving a problem in learning graphic design. With a minimum allocation of time in school, students can study at home through video guides presented in interactive multimedia.

Stage 6: After analyzing the needs in making interactive multimedia, the next step is to set the contextual delivery strategy of interactive multimedia based on Balinese culture. Before giving the soft copy of interactive multimedia based on Balinese cultural contextual to students, they should be explained the procedures for using interactive multimedia based on Balinese cultural contextual first. In the delivery strategy of interactive multimedia based on Balinese culture, cartoon animation illustrations as an explanation of the basics of graphic design that will give students the spirit of learning. In interactive multimedia based on Balinese culture, there is a question training menu that will be able to evaluate students' abilities related to graphic design theory.

Stage 7: The assembly stage is a stage in making interactive multimedia based on Balinese cultural contextual. The assembly stage includes the creation of an interactive multimedia contextual culture based on Balinese culture. In this stage the design is made with the Macromedia Flash 8 application which is an interactive multimedia maker application. Multimedia elements such as images, animation, text and sound will be integrated into an interactive multimedia product.

Stage 8: The trial included responses from content experts, media experts, design experts, and field trials. Each expert will be given a questionnaire with criteria according to the expertise of the experts.

The subjects of the trial of the product of the development research are:

1. Review stage of experts

The test subjects at this stage were carried out by experts in the field of study, learning design experts and instructional media experts. Experts in the field of study or subject matter in this development research are graphic design subject teachers at SMK 1 Sawan who have a minimum Bachelor's specification. Media experts and media design experts are other college lecturers who teach graphic design subjects, master and professionals in their fields.

2. Field testing stage

At this stage the trial subjects were conducted in X Multimedia class at SMK Negeri 1 Sawan. The test was carried out by individual tests totaling 3 students, a small group test consisting of 8 students from students who had received basic graphic design material, who are the students of class XI. And for field trials, questionnaires have been provided that are suitable for the characteristics of vocational students, which are more directed at the visual, audio \& animation display as well as text clarity and clarity of the material delivered in interactive multimedia based on Balinese cultural contextual. Field test participants were 32 students of class X Multimedia. 


\section{Result And Discussion}

Determining subjects that are the object of development are the basic subjects of Graphic Design. The following are the basic subjects of graphic design based on the syllabus of basic graphic design subjects.

\begin{tabular}{ll}
\hline No & Learning Activities/Basic Learning Material Graphic Design \\
\hline 1 & Observe to identify, formulate problems about graphic design \\
2 & $\begin{array}{l}\text { Collect data about graphic design (Introduction and development of graphic design) } \\
3\end{array}$ \\
& $\begin{array}{l}\text { Processing data about vector-based image design. Describe the product of vector graphic design, } \\
\text { the material about the banner is chosen. }\end{array}$ \\
4 & Communicate Corel Draw applications in vector-based image design. \\
\hline
\end{tabular}

Next, analyze everything that is needed in the development of drafts such as analysis of the objectives and characteristics of subjects, analysis of learning resources and analysis of student characteristics. In this case the researchers made observations related to the development of interactive multimedia such as searching for students' interests, facilities and infrastructure at the multimedia laboratories of SMK N 1 Sawan, analysis of the feasibility of software and hardware, and also human resource capabilities. In the process all those which appropriate with the requirements are developed into interactive multimedia based on Balinese cultural contextual products. Seeing the character of subjects with more practice compared to theory, the development of interactive multimedia based on Balinese contextual culture is considered very appropriate to be used to assist students in the teaching and learning process. Students can study at home by seeing and understanding the video tutorials that are displayed. The media development process, in this stage the software used to create interactive multimedia based on contextual Balinese culture on learning Graphic Design namely flash CS 5, for voice input using the Cool edit pro 2.1 application, and material recorder / video tutorial maker using the Camtasia studio 9 application, as well as Adobe Photoshop as an image editing software. That four softwares are synergized into interactive multimedia products. In the Camtasia application it is also able to converting a video into the .swf format, making it easier to call commands to the menu in interactive multimedia. Back sound in interactive multimedia is searched through YouTube create and audio library so as to avoid copyright in the use of music, besides that Camtasia is also able to input sound to be run directly into the video tutorial made.

The following are the results of the implementation of interactive multimedia based on Balinese cultural contextual learning on graphic design.

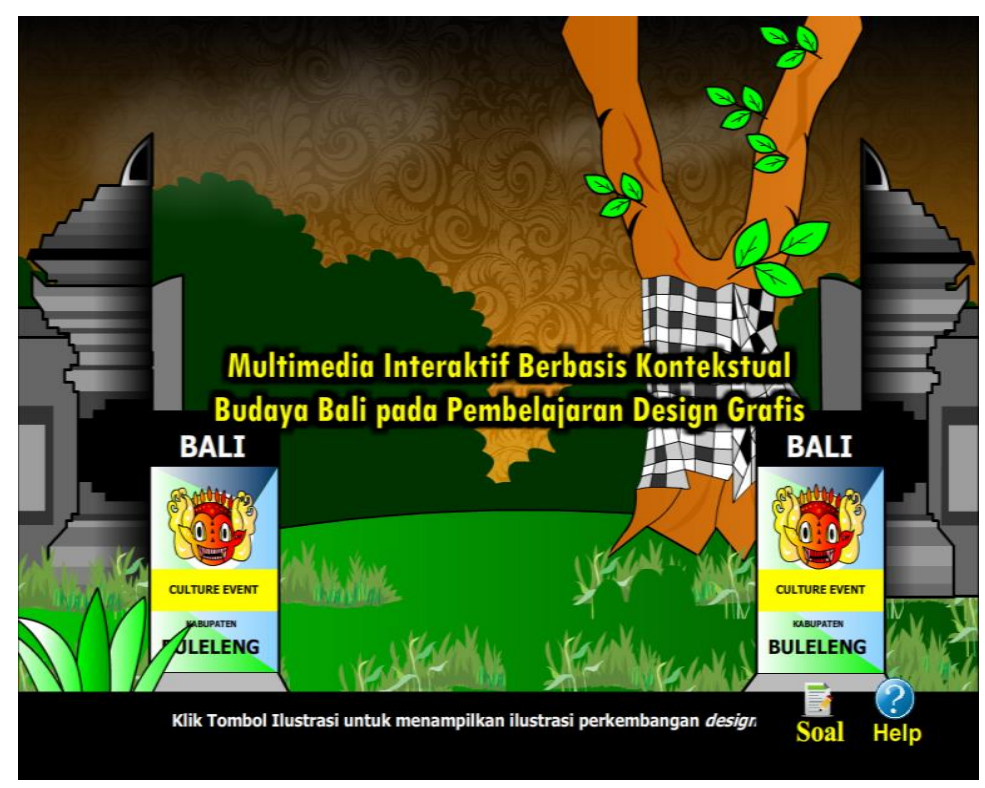

Picture 1. Main menu 
The next stage is the production stage, at this stage researchers directly distribute the results of product development into a soft copy. Then run the program with the master.exe file. Expert review and trial of the product. Trials include content expert responses that are directly adapted to the syllabus of basic graphic design subjects. Media experts, design experts, user / teacher trials while teaching, trials to find student responses in the form of individual tests, small groups and looking for student responses in one class. In the process each expert will be given a questionnaire with criteria that are according to the expertise of the experts, such as tests and revisions. In making decisions using Conversion Levels of Achievement with scale 5 by using descriptive analysis techniques.

Table 2. Scala 5 .

\begin{tabular}{lll}
\hline Achievement Level (\%) & Qualification & Description \\
\hline $90-100$ & Very good & No need to be revised \\
$75-89$ & Good & No need to be revised \\
$65-74$ & Enough & Revised \\
$55-64$ & Less & Revised \\
$0-54$ & Very less & Revised \\
\hline
\end{tabular}

Formula

(Arikunto, 2008:35)

$$
\begin{aligned}
& P=\frac{\sum(\text { answer } \times \text { highestweight })}{n \times \text { highestweight }} \times 100 \% \text { (Arikunto, 2008:35) } \\
& \text { Description: } \\
& \begin{array}{cl}
\mathrm{P} \quad: \text { Percentage } \\
\mathrm{n} \quad: \text { Total } \\
\mathrm{n} \quad \text { Number of all questionnaire items }
\end{array}
\end{aligned}
$$

a) Media expert assessment

Percentage of achievement level of interactive multimedia based on Balinese cultural contextual in learning graphic design based on media expert assessment as follows.

$$
P=\frac{\sum(\text { answer } \times \text { highestweight })}{n \times \text { highestweight }} \times 100 \%
$$

From that stage, the percentage of media expert evaluation results are calculated: $153: 180 \mathrm{x}$ $100 \%=85 \%$. Calculation results of $85 \%$ are in good qualifications, so that interactive multimedia based on Balinese cultural contextual learning on graphic design does not need to be revised.

\section{b) Design expert assessment}

Based on the results of the design expert evaluation, the percentage of the achievement level of interactive multimedia based on Balinese contextual culture in the graphic design learning as follows.

$$
P=\frac{\sum(\text { answer } \times \text { highestweight })}{n \times \text { highestweight }} \times 100 \%
$$

Based on that stage, then the percentage of the design expert test results is calculated: 89: $100 \times 100 \%$ $=89 \%$. Calculation results of $89 \%$ are in good qualifications, so that interactive multimedia based on Balinese cultural contextual learning on graphic design does not need to be revised.

\section{c) Expert content assessment}

Based on the assessment of content experts, it can be seen that the contents of learning materials in interactive multimedia are in accordance with the basic syllabus of graphic design subjects and do not need to be revised. 


\section{d) User / Teacher Assessment}

The material in interactive multimedia is in accordance with the criteria of an interactive multimedia on the basic graphic design subjects that will be used in the second semester of the Multimedia expertise program

\section{e) Individual Test}

Based on the responses of students in 3 individual tests, the whole answered "Yes" for the statement of pleasure in learning to use interactive multimedia based on Balinese contextual culture on learning graphic design and statements can run interactive multimedia without the help of the teacher.

\section{f) Small group test}

Based on the results of the small group test, it can be calculated the percentage of the level of achievement of interactive multimedia based on Balinese contextual culture on learning graphic design as follows,

$$
P=\frac{\sum(\text { answer } \times \text { highestweight })}{n \times \text { highestweight }} \times 100 \%
$$

Based on that stage, then the percentage of the design expert test results are calculated: 90: $100 \mathrm{x}$ $100 \%=90 \%$. Calculation results of $90 \%$ are in very good qualifications, so that interactive multimedia based on Balinese contextual culture on graphic design learning does not need to be revised.

\section{g) Field Test (Student Response)}

Percentage $=87: 100 \times 100 \%=87 \%$. Calculation results of $87 \%$ if converted with achievement table conversion level with 5 scale calculation results are in good qualification, so that interactive multimedia based on Balinese contextual culture on graphic design learning does not need to be revised.

In the process of developing interactive multimedia namely determining subjects that are the object of development and analyzing everything needed in the development of drafts such as analysis of the objectives and characteristics of subjects, analysis of learning resources to analysis of characteristics of students who produce preliminary data before developing interactive multimedia. The data was analyzed to find a way out of the problems found in SMK 1 Sawan, then designing storyboards. The results of storyboard design will be a reference in making the display at the implementation stage in product development (Binanto, 2010). One of the advantages of creating a design using storyboards is that the user has a broader scope / insight to manage the design flow so that it gets a stronger effect or interest. In addition, with the visualization, a group of people or organizations of multimedia developers are able to exchange ideas together to place ideas on the storyboard and rearrange the storyboard (Reinald, 2011). The next stage is the stage of product distribution, which is packed on DVD. The application of Balinese contextual culture-based models has proven successful in improving student responses in graphic design learning seen from the results of the experiments carried out

\section{Conclusions and Recommendations}

Based on the results of data analysis and research discussion on the development of interactive multimedia based on Balinese contextual culture on graphic design learning, it can be concluded as follows,

1. The design of interactive multimedia based on Balinese cultural contextual on graphic design learning is made using story board design and activity diagrams. The implementation using Adobe Flash software, Adobe Photoshop, Cool Edit Pro and Camtasia.

2. Interactive multimedia products based on Balinese contextual culture on graphic design learning according to content experts from the results of development on the aspects of material content presented, feasibility of presentation and feasibility of effective language is feasible to be used in groups of multimedia productive subjects, especially in graphic design learning in class X Multimedia at SMK Negeri 1 Sawan. This is based on the results of the assessment of content experts who have adjusted the subject matter with SK/KD learning graphic design. The results of the development of aspects of the concept of learning, the learning process, teaching procedures are effective and worthy of use. This is based on the assessment of the user/teacher test.

3. Interactive multimedia products based on Balinese cultural contextual on learning graphic design from the development results on aspects of learning, curriculum, content, interface design, feedback and problem handling are effective and feasible to use in the class X Multimedia at SMK Negeri 1 Sawan in graphic design learning. This is based on the assessment of design experts with good qualifications and 
does not need to be revised. Interactive multimedia products based on Balinese contextual culture on graphic design learning from the development of the coloring aspects, the use of words and languages, graphics, animation, video, sound / audio, program operations, program security, error handling, and physical quality of packaging are effective and suitable for use in class X Multimedia at SMK Negeri 1 Sawan in graphic design learning. This is based on the assessment of media experts with good qualifications.

4. Interactive multimedia products based on Balinese contextual culture on graphic design learning from the results of development in aspects of clarity, appearance and error, can be accepted and feasible to be used in class X Multimedia at SMK Negeri 1 Sawan in graphic design learning. This is based on an individual test assessment. Furthermore, from the results of the development on the aspects of wear, implementation and usefulness of the program, it is effective to be used in theclass X Multimedia of SMK Negeri 1 Sawan in graphic design learning, this is based on the assessment of the small group with very good qualifications. Interactive multimedia products based on Balinese contextual culture on graphic design learning from the results of development on the aspects of the implementation and usefulness, effectively feasible to be used in the class X Multimedia at SMK Negeri 1 Sawan in graphic design learning. This is based on a well-qualified field test assessment.

Based on observations, several things that can be taken into consideration for follow-up include the following: 1. Researchers recognize that Balinese contextual culture-based interactive multimedia on graphic design learning still has many weaknesses. In terms of material substance, appearance, interactivity and many other weaknesses. Therefore, the researcher can then present more complete subject matter, and making multimedia to be more interactive and uplifting the nuances of local culture, 2. The development of interactive multimedia based on Balinese cultural contextual in learning graphic design was piloted in vocational multimedia skills programs at other schools and 3. Other researchers can try the development of multimedia-based interactive multimedia..

\section{References}

Arikunto, S. 2008. Dasar-dasar evaluasi. Jakarta: Bumi aksara.

Ghufron, Anik dkk. 2007. Panduan Penelitian dan Pengembangan Bidang Pendidikan dan Pembelajaran. Yogyakarta: Lembaga Penelitian UNY.

Lee, Szu Hsin;Tseng, Hui Ching, 2008. "Investigation of Technology Integrated Instruction in Art Education: A Case Study of Exploring Learning Achievement" Journal of Educational Multimedia and Hypermedia, 17 (3), pg. 337-361.

Mochamad Miswar Hadibin, Bambang Eka Purnama, Gesang Kritianto, 2012.“Pembangunan Media Pembelajaran Teknik Komputer Jaringan Kelas XSemster Ganjil Pada Sekolah Menengah Kejuruan Taruna Bangsa PatiBerbasis Multimedia Interaktif", Jurnal Speed 13, Vol 9 No 2:432-437.

Sudarma, I K. \& I M. Tegeh. 2007. Penelitian Pengembangan (Pengembangan Produk-Produk di Bidang Teknologi Pendidikan). Makalah Disajikan dalam Pelatihan Penyusunan Proposal Penelitian Pengembangan di Jurusan Teknologi Pendidikan Undiksha. Singaraja:Januari.

Sugiyono. 2013. Metode Penelitian Pendidikan (Pendekatan Kuantitatif, Kualitatif, dan R\&D), Bandung : Alfabeta.

Trianto. 2007. Model-model Pembelajaran Inovatif Berorientasi Konstruktivistik. Jakarta : Prestasi Pustaka

Uno,Hamzah.(2009). Model Pembelajaran Menciptakan Proses Belajar Mengajar yang Kreatif dan Efektif.Jakarta: PT Bumi Aksara

Wang, Ling, 2008. "Developing and Evaluating an Interactive Multimedia Instructional Tool: Learning Outcomes and User Experiences of Optometry Students", Journal of Educational Multimedia and Hypermedia,17(1) pg. 43-57. 